\section{Can Haitian Higher Education Rise from the Rubble?}

\author{
HARRY E. DUMAY
}

Harry E. Dumay is associate dean for finance and chief financial officer at Harvard University's School of Engineering and Applied Sciences. He also serves as an external evaluator on a three-year US Agency for International Development-funded partnership grant between the University of Massachusetts Boston and the State University of Haiti. E-mail: dumay@seas.harvard.edu.

$\mathrm{T}_{\mathrm{h}}^{\mathrm{h}}$ he January I2 earthquake dealt a devastating blow to Haiti's already struggling higher education and brought it to a halt. Yet, Haiti is determined to rebuild. In this reconstruction effort, great care must be taken not just to restore what existed but to erect a better system.

\section{Catastrophic Damage}

During the 35 -second quake, the sole building that housed the University of Port-au-Prince crumbled, trapping hundreds of students and faculty members under its fallen concrete slabs. At the State University of Haiti, the Faculty of Linguistics collapsed: the dean, several faculty members, and more than three hundred students lost their lives. Most buildings at the State University and at private institutions such as the Episcopalian University and University Quisqueya were either destroyed or declared unsafe. To date, the death toll for the university community has not been confirmed. Most institutions cannot predict when activities will resume.

Haitian higher education was already in a precarious state prior to January I2. Lack of access, a weak governance structure, and the absence of a true professoriate constituted three of its many problems.

\section{LACK OF ACCESS}

Estimated at only I percent, access remains at the elite level in Haiti. A comparison with the Dominican Republic, Haiti's neighbor, is illustrative. Out of a population of 9 million, the Dominican Republic enrolled I74,62I students in I997. Haiti's enrollment is estimated at I5,000 for a population of 8.5 million. Even among the students that made it into college, in 200878 percent indicated that they could not enroll in their desired concentration.

\section{Dysfunctional Governance}

Governance is problematic within the State University of Haiti, first. The rectors, vice-rectors, and deans are all elected by students and faculty members. They feel more accountable to their political constituency than to their leadership. Conscious of their political clout, a few activist students, often manipulated by ambitious faculty members, frequently protest to demand leadership changes. For example, a student strike at the Faculty of Medicine paralyzed all academic activities from April 2009 until the time of the earthquake. Second, governance is also problematic across the higher education system. The State University is mandated to oversee the private institutions that compete with it for students. Some private institutions feel that they are better run than the State University and resent this oversight function. Finally, the lack of appropriate standards and effective supervision has given rise to a number of pseudouniversities.

\section{A Nonexistent Professoriate}

The academic profession is not existent in Haiti. The most recent reliable statistic on the entire system dates from I987 and indicated that 93 percent of professors worked part time and that only 26 percent had a graduate degree. Degree attainment among professors has somewhat improved since then. However, the majority of faculty members still have another full-time job that they combine with as many teaching opportunities as possible to enjoy a decent standard of living.

\section{The Case for Rebuilding}

With hundreds of thousands of people still homeless and the hurricane season nearing, is higher education a current priority for Haiti? The Haitian government and higher education officials answer this question in the affirmative. They are determined to rebuild Haiti's schools for internal as well as external reasons.

Since I8I5 when the first Haitian postsecondary institution was founded, higher education has always played an important internal role to form the nation's elite. The provision of free, public higher education is viewed as one of the government's responsibilities. In turn, the State University of Haiti and the many private institutions that have sprung up since the I980s have formed the majority of the country's professionals, technocrats, and politicians.

During the 35-second quake, the sole building that housed the University of Port-au-Prince crumbled, trapping hundreds of students and faculty members under its fallen concrete slabs.

Achieving economic growth constitutes the other reason why Haitians believe that they must rebuild higher education. Human capital theorists consider education as indispensable for economic progress, because it leads to innovation. Joseph Schumpeter and other development economists assert that innovation yields nonincremental growth, the kind that the poorest countries need to leapfrog out of poverty. The Millennium Development Goals echo those theories by deeming science and technology necessary for the least-developed 
countries to prosper. Consequently, Haitians believe that the nation must form its next generation of professionals and innovators in order to be a viable state, one that does not rely on the international community for all its needs.

In the aftermath of the earthquake, many foreign universities and international institutions have expressed an interest in helping. Clearly, it would be a mistake to rebuild within the same framework that existed. Improvement in the areas of access, governance, and the academic profession can ensure that the new system is better than the old.

The State University is mandated to oversee the private institutions that compete with it for students. Some private institutions feel that they are better run than the State University.

\section{INCREASING ACCESS}

Some of the national reconstruction plans that are being elaborated already include ideas that could help to increase access. One such proposal is the decentralization of activities away from the capital city. Currently, all the major postsecondary institutions have their main campus in Port-au-Prince. The costs and logistical difficulties associated with relocating to Port-au-Prince have kept college out of the reach of many young people. The decentralization of programs and campuses throughout Haiti would alleviate this problem. Another plan that could potentially increase enrollment is the State University's project to consolidate its previously physically dispersed campuses. Colocation of faculties should permit campuses to avoid duplicating the same general education courses in various units and to offer more flexible schedules, thus, making it easier to accommodate more students.

\section{Establishing Governance and Coordination}

The State University of Haiti should follow the lead of betterrun private institutions and stop electing its officials. An independent university board of trustees should appoint the rector and hold him or her accountable to run the institution. A parallel higher education board in the Ministry of Education should provide oversight to both public and private institutions. The board's effective coordination of these institutions should involve providing them with incentives to cooperate and share services to benefit from economies of scale. Indeed, no single institution has sufficient resources even for some of the minimal requirements: updated library systems, information technology, and laboratory facilities. It would be a waste of international aid to replicate several suboptimal facilities at various institutions.

\section{InVesting in Full-Time Faculty}

To improve the quality of teaching and introduce research, the system should strive to support more full-time faculty members and ensure their presence on campus. This implies adjusting salaries to enable someone to live decently with just a faculty appointment. How does one accomplish this fiscally? Budget increases cannot be expected in the public system, given the government's near-bankrupt state. Reductions in administrative expenses should take place and can help but will not provide all the funds needed. As for private institutions, the high level of price sensitivity in Haitian households makes it impractical for them to pass this cost onto students. This is where the international community can help. Aid and collaboration should be aimed at supplementing faculty salaries for meritorious research efforts that advance knowledge and thus benefit the global community of scholars.

\section{CONCLUSION}

The Haitian higher education system must be rebuilt. It is the key to the country's long-term economic independence. Undeniably, that task will be enormous. However, if well done, it could offer opportunities for a significant renewal and serve as a model for reconstruction in other sectors.

\section{The Asian Higher Education Century?}

\section{Philip G. Altbach}

Philip G. Altbach is Monan University Professor and director of the Center for International Higher Education at Boston College.

The 2009 world university rankings showed a modest 1 increase in the number of universities in Asia that have entered the top I00-in the Shanghai Academic Ranking of World Universities from 5 to 6 , and in the Times Higher Education/QS rankings from I4 to I6. Commentators immediately referred to the academic rise of Asia and a concomitant decline of the West. Fundamentally, however, academic excellence, research productivity, and reputation, which are mainly what the rankings capture, are not a zero-sum game. The improvement of universities in one part of the world does not mean that institutions elsewhere necessarily decline. Further, the shift to Asia is by no means dramatic. It is in fact a good thing that universities outside the traditional powerhouses of North America and western Europe are improving and gaining increased recognition for their work. 